\title{
PREVALENCE OF IRON DEFICIENCY AMONG SCHOOL GOING ADOLESCENT FEMALES IN RURAL AREA OF WARDHA DISTRICT OF MAHARASHTRA.
}

Sarika More, Sumeet Shende

1. Assistant Professor, Department of Pathology, Sri Lakshmi Narayana Institute of Medical Sciences,Pondicherry.

2. Assistant Professor, Department of Forensic Medicine, Sri Lakshmi Narayana Institute of Medical Sciences,Pondicherry.

\section{CORRESPONDING AUTHOR}

Dr. Sarika More

Assistant Professor

Department of Pathology

Sri Lakshmi Narayana Institute of Medical Sciences,

Osudu, Pondicherry

E-mail: dr.sarikamore@rediffmail.com

Ph: $00917639655845,00919655467965$.

ABSTRACT: BACKGROUND: Anemia continues to be a major public health problem worldwide, particularly in the developing country settings. The prevalence of anemia in females is disproportionately high in the developing countries mainly due to poverty, inadequate diet, malaria and other parasitic infection, poor access to health services and repeated pregnancy.AIM: The aim of this study is to find out the prevalence of anemia, in school going adolescent females in the age group of 12-15yrs in a village school and to know the prevalence of iron deficiency in both the anemic and non anemic school going adolescent females in a village school. MATERIAL AND METHODS: Present study is carried out in the Department of Pathology, Rural Medical College in Maharashtra situated in Central India. A secondary school in the neighborhood, having hundred girl students in the age group of 12-15years studying in VI to IX standard was selected. Screening for anemia and iron deficiency was done by: 1.Complete blood count: done by automatic cell counter i.e. Coulter for hemoglobin concentration.2.Estimation of serum ferritin concentration: was done by ELISA. RESULT: 63 of 100 girl students had hemoglobin levels less than $12 \mathrm{gm} \%$. Anemia (hemoglobin $<12 \mathrm{gm} \%$ ) was present in $63 \%$ (63 out of 100) girls. Out of 63 girls who were anemic, 50 girls had reduced serum ferritin. Since the total number of students was 100, thus the prevalence of iron deficiency anemia was 50\%. CONCLUSION: Iron deficiency is the major cause of anemia and most common nutritional disorder in our country and remains a formidable health challenge. Females in the period of later school age and early adolescence are prone to develop iron deficiency because, the nutrient requirements are high as the reserves are being laid for the subsequent rapid pubertal growth spurt, menstrual loss and also due to limited dietary iron intake

KEY WORDS: Anemia, Iron deficiency, adolescent female.

INTRODUCTION: Iron deficiency anemia was apparently a recognized illness in the ancient Egypt and was known to Hippocrates. Choloris, named the "green sickness" because of pallor it produced, was found in the $17^{\text {th }}$ century responsive to iron therapy. A recent publication sited iron deficiency as the third greatest global health risk after obesity and unsafe sex ${ }^{1}$. Anemia 
resulting from iron deficiency affects approximately 2 billion people or $34 \%$ of the world population ${ }^{2}$. Iron deficiency is not limited to developing countries and is the main cause of anemia in the United States. According to the third National Health and Nutritional Examination Survey (NHANES III) data, iron deficiency is prevalent in $9 \%$ of toddlers and up to $11 \%$ of adolescent females in the United States. Iron deficiency anemia most severe stage of iron deficiency (defined as a low hemoglobin concentration with iron deficiency) was found in $3 \%$ of the adolescent females ${ }^{3}$

In defining iron deficiency as the point at which iron stores are completely exhausted, where in even small functional iron deficits will be associated with certain liabilities both hematological and non hematological. Iron deficiency can be diagnosed by showing that there is no stainable iron in the reticulo endothelial cells in bone marrow smears or, more easily, by a low concentration of ferritin in serum $(<12 \mu \mathrm{g} / \mathrm{l})$. Laboratory measurement of serum ferritin has emerged as the single most important indicator of iron deficiency. ${ }^{4}$ It is the main test for iron assessment whether performed to screen healthy individuals for the latent iron deficiency or to diagnose iron deficiency in an overtly anemic patients ${ }^{4}$.In healthy individuals the level of serum ferritin provides a reliable measure of storage iron 5 . The overriding advantage of measuring serum ferritin is that a value of less than $12 \mu \mathrm{g} / \mathrm{l}$ in a patient is diagnostic iron deficiency ${ }^{6}$.

Previously very few studies have been carried out to assess the prevalence of iron deficiency among school going adolescent females in India. In present study effort has been made to find out the prevalence of anemia, in school going adolescent females in the age group of 12-15 years in a village school and to know the prevalence of iron deficiency in both the anemic and non anemic school going adolescent females in a village with the use of serum ferritin level.

MATERIAL AND METHOD: The present study was carried out in the Department of Pathology in a rural medical college, Maharashtra. Approval was obtained from the Institutional Ethics Committee for the study.

SELECTION OF SUBJECTS: A secondary school in the neighborhood, having girl's student in the age group of 12-15years studying in VI to IX standard was selected. Necessary permission was taken from the school authority and girls were explained in detail about the study in the school assembly. Participation in the screening programme was voluntary. An explanatory letter and consent form was given to all the girls who attended the school and was distributed in the science class. Written consent was obtained from parents or guardian for participation in the screening. Participants completed a questionnaire asking for significant family, medical and menstrual history, parent's education and their dietary habits.

\section{METHOD OF SCREENING:}

Screening for anemia and iron deficiency was done by:

1. Complete blood count: done by automatic cell counter i.e. Coulter for hemoglobin concentration.

2. Estimation of serum ferritin concentration: was done by ELISA

Blood samples were collected by using aseptic precautions by qualified and experienced phlebotomists. Around $4 \mathrm{ml}$ of blood was collected, $2 \mathrm{ml}$ in plain bulb and $2 \mathrm{ml}$ in EDTA bulb. 
From plain bulb serum was separated and kept at - 20 degree Celsius for serum ferritin estimation and EDTA sample was used for complete blood count which was done by automatic cell counter, provided the hemoglobin concentration.

Serum ferritin was done by ELISA .For this the recommended protocol by the kit used was followed.

PRINCIPLE OF THE TEST: Antihuman-ferritin antibodies are bound to micro wells. Ferritin present in diluted serum or plasma, bind to the respective antibody. Washing of the micro wells removes unspecific serum and plasma components. Horseradish peroxides (HRP) conjugated antihuman ferritin, immunologically detects the bound patients ferritin forming a conjugate/ferritin/antibody complex. Washing of the micro wells removes unbound conjugate. An enzyme substrate in the presence of bound conjugate hydrolyzes to form a blue color. The addition of an acid stops the reaction forming a yellow end-product. The intensity of this yellow color is measured photometrically at $450 \mathrm{~nm}$. The amount of colour is directly proportional to the concentration of ferritin present in the sample.

\section{PROCEDURE OF THE TEST:}

1. Pipette $25 \mu \mathrm{l}$ calibrator, control and patient sample and add $100 \mu \mathrm{l}$ sample buffer.Incubate for 30 minutes at room temperature.Discard the contents of the wells and wash 3 times with $300 \mu$ of wash solution.

2. Pipette $100 \mu$ l enzyme conjugate. Incubate for 15 minutes at room temperature.Discard the contents of the wells and wash 3 times with $300 \mu$ of wash solution.

3. Pipette $100 \mu \mathrm{l}$ substrate solution.Incubate for 15 minutes at room temperature.

4. Add $100 \mu \mathrm{l}$ of stop solution. Leave untouched for 5 minutes.Read at $450 \mathrm{~nm}$

INTERPRETATION OF RESULTS: First the average optical densities were calculated for each calibrator. Then by using line- log graph paper the average optical density of each calibrator versus the concentration was plotted. The best fitting curve approximating the path of calibrator was drawn. The calibrator points may also be connected with straight line segment. The concentrations of unknowns were then estimated from the calibration curve by interpolation.

Established age adjusted values for hemoglobin and serum ferritin were used.

The participants after screening were divided into three groups:

\begin{tabular}{|l|l|l|}
\hline \multicolumn{1}{|c|}{ GROUP I } & \multicolumn{1}{|c|}{ GROUP II } & \multicolumn{1}{|c|}{ GROUP III } \\
\hline $\begin{array}{l}\text { Participants who were } \\
\text { anemic (Hb.<12gm \%) and } \\
\text { iron deficient (Serum } \\
\text { ferritin less than } 12 \mu \mathrm{g} / \mathrm{l})\end{array}$ & $\begin{array}{l}\text { Participants who were non } \\
\text { anemic (Hb concentration of } \\
12 \mathrm{gm} \% \text { or more) and iron } \\
\text { deficient (serum ferritin level } \\
<12 \mu \mathrm{g} / \mathrm{l})\end{array}$ & $\begin{array}{l}\text { Participants who } \\
\text { hemoglobin concentration of } \\
12 \mathrm{gm} \% \text { or more and serum } \\
\text { ferritin levels of } 12 \mu \mathrm{g} / \mathrm{l} \text { or } \\
\text { more }\end{array}$ \\
\hline
\end{tabular}


RESULTS: 100 students were tested for hemoglobin concentration, serum ferritin. 63 of 100 girl students had hemoglobin levels less than $12 \mathrm{gm} \%$ and 37 had hemoglobin levels above $12 \mathrm{gm} \%$. Anemia (hemoglobin $<12$ gm \%) was present in 63\% (63 out of 100) girls. Thus, prevalence of anemia in school going adolescent females was $63 \%$. The overall mean hemoglobin in the study was $11.66 \pm 1.27$. The mean hemoglobin levels were 12.80 in nonanemic girl students and 10.99 in anemic students respectively with $p$ value $<0.0001$ which is statistically significant.

Out of the 63 girl students who had anemia, 56 girls (56\%) had Hb values between 10-12 gm\%, 5 girls (5\%) had $\mathrm{Hb}$ values between 7-10 gm\% and rest of the 2 girls (2\%) had Hb values below 7 gm $\%$. Thus, mild anemia (Hb10-12 gm \%) was present in 56\% of the study subjects, moderate anemia ( $\mathrm{Hb} 7-10 \mathrm{gm} \%)$ in $5 \%$ and severe anemia ( $\mathrm{Hb}<7 \mathrm{gm} \%)$ was present in only $2 \%$ of the study subjects.

On analyzing the questionnaire which included relevant family history, parent's education, dietary history and other relevant history of anemic and non anemic student, Parent's education level showed no statistically significant difference ( $p$ value $=0.21$ ) between anemic and non anemic students. No statistical significant difference (p value 0.11 ) was observed between the dietary habbits of anemic and non anemic students.

Serum ferritin was done in 100 girl students between the age group of 12 -15 years, 67 were iron deficient (serum ferritin $<12 \mu \mathrm{g} / \mathrm{l}$ ). So the prevalence of iron deficiency was $67 \%$. Out of 63 girls who were anemic, 50 girls had reduced serum ferritin. Since the total number of students was 100, thus the prevalence of iron deficiency anemia was $50 \%$ and rest of the 13 girls who were anemic, the cause of anemia was other than iron deficiency.

To know the probable cause of anemia in these 13 girls who were anemic but were not iron deficient, further investigation in the form of peripheral smear examination, reticulocyte count and electrophoresis was done. 4 out of the 13 students were found to be sickle cell trait, 1 was sickle cell disease, 1 was thalassemia minor and 7 were macrocytic anemia probably due to vitamin B12 and folic acid deficiency.

These 13 students who were anemic but not iron deficient were excluded from the study. Anemia with iron deficiency was present in 50 girl students (group I), 17 students were non anemic iron deficient (group II) and 20 students were non anemic non iron deficient (group III).

Mean serum ferritin and hemoglobin levels in group I (anemic iron deficient) was 8.45 $\mu \mathrm{g} / \mathrm{L}$ and $11.01 \mathrm{gm} \%$. In group II (nonanemic iron deficient) it was $10.05 \mu \mathrm{g} / \mathrm{L}$ and $12.61 \mathrm{gm} \%$ respectively. Whereas, in group III (nonanemic non iron deficient) the mean serum ferritin and mean hemoglobin level was $25.27 \mu \mathrm{g} / \mathrm{L}$ and $12.97 \mathrm{gm} \%$.

DISCUSSION: Prevalence of anemia in various region /places in India by different authors is shown in table no.1.It is as high as $96.5 \%$ in Odisha ${ }^{11}$ to as low as $15.3 \%$ in Bangalore ${ }^{12}$. In present study prevalence of anemia in school going adolescent female is $63 \%$ Serum ferritin was done in 100 girl students, 67 were iron deficient (serum ferritin $<12 \mu \mathrm{g} / \mathrm{l}$ ). Thus the prevalence of iron deficiency was 67\%.According to the third National Health and Nutritional Examination Survey (NAHANSIII); ${ }^{3}$ In United States $11 \%$ of the adolescent females are iron deficient. In Western Iran a study done by Akramipour R et al (2008) ${ }^{7}$ the prevalence was $23.7 \%$, whereas in urban Bangladesh a study done by Ahmed F et al (2000) 8 it was only $17 \%$.

In India till date very few studies have been done to know the prevalence of iron deficiency using serum ferritin or/and transferrin saturation criteria. Basu et al (2005) ${ }^{9}$ in a study done in government schools of Chandigarh found the prevalence to be as high as $81.8 \%$ 
compared to our study in which the prevalence is $67 \%$. The reason for comparative high prevalence in the study of Basu et al (2005) ${ }^{9}$ may be because they have taken cutoff of iron deficiency as $<15 \mathrm{ng} / \mathrm{ml}(15 \mu \mathrm{g} / \mathrm{l})$. In all the recent studies including ours the cutoff of iron deficiency is $<12 \mu \mathrm{g} / \mathrm{l}$.

PREVALENCE OF IRON DEFICIENCY ANEMIA:Out of the 63 girls who were anemic, 50 girls had reduced serum ferritin. Since the total number of study subjects were 100 the prevalence of iron deficiency anemia $(\mathrm{Hb}<12 \mathrm{gm} / \mathrm{dl}$ and serum ferritin $<12 \mu \mathrm{g} / \mathrm{l})$ is $50 \%$. Iron deficiency anemia constituted $79 \%$ of all anemias in the present study.

In United States the prevalence of iron deficiency anemia is only 3\% (NAHANSIII); ${ }^{3}$ whereas in the study done in Western Iran by Akramipour R et al (2008) ${ }^{7}$ the prevalence of iron deficiency anemia was $21.4 \%$. In India Chandigarh, the prevalence of iron deficiency anemia was $11.4 \%$ in school going adolescent females.

In the present study the high prevalence of iron deficiency anemia (50\%) is difficult to explain exclusively on the basis of low bio-available dietary iron. Other factors may be playing a role, most likely excess iron loss due to parasitism.

In most of the studies prevalence of iron deficiency is much more than the prevalence of iron deficiency anemia. Iron deficiency anemia is manifestation of severe form of iron deficiency.

Three fourth of all the anemic students had decreased serum ferritin. Iron deficiency constituted $79 \%$ of all anemia, this is similar to the findings of Choudhary A et al (2006) ${ }^{10}$ where in also three fourth of all anemic were iron deficient. In the study done in Western Iran by Akramipour R et al (2008) 57.3\% of anemic girls were iron deficient.

CONCLUSION: - Prevalence of anemia among adolescent female is quite variable in different places of India. It depends upon socioeconomic factors, dietary habbits, infection especially malaria and also worm infection. The higher prevalence of mild anemia, demands due emphasis so as to bring down total prevalence of anemia in school going adolescent females. Special emphasis should be given for nutrient supplement especially iron and vitamins in this age group as there are chances of iron deficiency due to rapid pubertal growth spurt, menstrual loss and also due to limited dietary iron intake. Firm policies should be developed for vitamin and mineral supplementation in adolescents with political commitment.

\section{BIBLIOGRAPHY}

1. Rosnethal A M.WHO names top 10 health risks -Environ Health Perspect 2003; 111:A456.

2. Boccio J R, Ventkatesh I. Iron deficiency causes, consequences and stratification to overcome the nutritional problem. Biol Elemnet Res 2003; 94:1-31.

3. Centre for disease control and prevention. Recommendations to prevent and control iron deficiency in the United States .MMWR morle mortal wkly Rep 1998;47(RR-3):1-29

4. Cook JB \& Skikne BS. Iron deficiency: definition and diagnosis .Journal of internal Medicine 1989; 226:149-55.

5. Cook J D, Lipschitz DA, Miles LE, Finch CA. Serum ferritin as a measure of iron stores in normal subjects. American Journal of Clinical nutrition1974;27:681-687

6. Cook J D. Clinical evaluation of Iron deficiency. Serum Haematol 1982;19:6-18 
7. Akramipour R, Rezaei M, Rahimi Z. Prevalence of iron deficiency anemia among adolescent schoolgirls from Kermanshah, Western Iran. Hematology 2008 ;13(6):352-5

8. Ahmed F, Khan MR, Islam M, Kabir I, Fuchs GJ. Anaemia and iron deficiency among adolescent schoolgirls in peri-urban Bangladesh. Eur J Clin Nutr 2000 ;54(9):678-83

9. Sabita B, Srikanta B, Hazarika R \& Parmar V. Prevalence of anemia in school going adolescents of Chandigarh. Indian Pediatrics 2005; 42:593-597.

10. Choudhary A, Moses PD, Mony P, Mathai M. Prevalence of anemia among adolescent girls in the urban slums of Vellore, South India. Trop Doct 2006; 36(3):167-9

11. Bulliyy G, Mallick G, SethyGS, Kar SK.Hemoglobin status of non-school going adolescent girls in three districts of Orrisa, India. Int J Adolesc Med Health.2007; 19(4):395-406.

12. Muthayya S,Thankanchan P,Zimmermann MB,Anderson M,et al.Low anemia prevalence in school aged children in Banglore,South India: possible effect of school health initiative.Eur J Clin Nutr 2007;61(7):865-9

13. Kapoor G, Aneja S. Nutritional disorders in adolescent girls; Indian Pediatrics 1992;29:969-973

14. Sidhu S, Kumari K and Uppal M. Prevalence of anemia among adolescent girls of schedule caste community of Punjab. Anthropologist 2005; 7(4):265-267.

15. Sen A and Kanani SJ. Deleterious functional impact of anemia on young adolescent school girls. Indian Pediatrics 2006;43: 219-226

Table No.1 .Prevalence of anemia in various region /places in India by different authors.

\begin{tabular}{|c|c|c|}
\hline Authors & Region / Places & Prevalence \\
\hline Basu et al (2005) ${ }^{9}$ & Chandigarh & $23.9 \%$ \\
\hline Chaudhary A et al (2008)10 & Vellore & $29 \%$ \\
\hline Bulliyy G et al (2007) ${ }^{11}$ & Orissa & $96.5 \%$ \\
\hline Muthayya S et al(2007) ${ }^{12}$ & Bangalore & $15.3 \%$ \\
\hline Kapoor G et al(1992) ${ }^{13}$ & Delhi & $50.3 \%$ \\
\hline Sidhu S et al.(2005)14 & Punjab & $70.57 \%$ \\
\hline Sen A and Kanani $(2006)^{15}$ & Gujarat & $67 \%$ \\
\hline
\end{tabular}

Table No.2. Showing mean hemoglobin level in anemic and non anemic adolescent girl students.

\begin{tabular}{|l|l|}
\hline \multicolumn{2}{|l|}{ Mean hemoglobin levels ( $\mathrm{p}$ value $<0.0001$ ) } \\
\hline Nonanemic & $12.80 \pm 0.65$ \\
\hline Anemic & $10.99 \pm 1.05$ \\
\hline
\end{tabular}


Table No.3. Showing number of students in different groups

\begin{tabular}{|l|c|}
\hline Groups & Number of students \\
\hline Anemic iron deficient (group I) & 50 \\
\hline Nonanemic iron deficient (group II) & 17 \\
\hline Nonanemic non iron deficient (group III) & 20 \\
\hline
\end{tabular}

Table No.4. Showing mean serum ferritin $\&$ hemoglobin levels:

\begin{tabular}{|c|c|c|}
\hline & $\begin{array}{l}\text { Mean serum ferritin } \\
\qquad(\mu \mathrm{g} / \mathrm{L})\end{array}$ & $\begin{array}{c}\text { Mean hemoglobin levels } \\
\text { (gm \%) }\end{array}$ \\
\hline $\begin{array}{l}\text { Anemic iron } \\
\text { deficient (group I) } \\
(n=50)\end{array}$ & $8.458 \mu \mathrm{g} / \mathrm{L}$ & $11.01 \mathrm{gm} \%$ \\
\hline $\begin{array}{l}\text { Nonanemic iron } \\
\text { deficient (group II) } \\
(\mathrm{n}=17)\end{array}$ & $10.02 \mu \mathrm{g} / \mathrm{L}$ & $12.61 \mathrm{gm} \%$ \\
\hline $\begin{array}{l}\text { Nonanemic non } \\
\text { iron deficient } \\
\text { (group III) } \\
(\mathrm{n}=20)\end{array}$ & $25.275 \mu \mathrm{g} / \mathrm{L}$ & $12.975 \mathrm{gm} \%$ \\
\hline
\end{tabular}

